MEDIALOG: Jurnal IImu Komunikasi, Volume III, No. II, Agustus 2020, hlm 13-23

\title{
PENGARUH PROGRAM ACARA KONSER TOMBO KANGEN IN MEMORIAM DIDI KEMPOT DAN DAYA TARIK IKLAN TERHADAP KEPUTUSAN MELAKSANAKAN DONASI (SurveyPada Followers @didikempot_official)
}

\author{
Ilona Vicenovie Oisina Situmeang ${ }^{1}$ \\ ${ }^{1}$ Universitas Persada Indonesia, Jakarta. \\ Email: ilonaoisina@yahoo.com
}

\begin{abstract}
ABSTRAK
Program acara konser Tombo Kangen In Memoriam Didi Kempot disiarkan digital live di iNews Senin, 25 Mei 2020 mengumpulkan dana yang dikordinasikan Pemkab Ngawi melalui Bank Jatim untuk dikembalikan ke daerah Ngawi dan didistribusikan kepada korban corona. Tujuan penelitian untuk mengetahui seberapa besar pengaruh program acara konser Tombo Kangen In Memoriam Didi Kempot dan Daya Tarik Iklan Terhadap Keputusan Melaksanakan Donasi. Penelitian ini menggunakan tradisi Sosiopsikologis dan Teori Elaboration Likehood (ELT). Desain Penelitian menggunakan Paradigma Positivisme, Pendekatan Kuantitatif, Jenis Eksplanatif dan Metode Survey. Populasi adalah followers @ didikempt_oficial sebanyak 525.000 responden, dan sampel 100 responden. Hasil yang diperoleh hubungan rendah program acara konser Tombo Kangen In Memoriam Didi Kempot terhadap keputusan melaksanakan donasi koefisien korelasi sebesar 0.312. Hubungan kuat Daya Tarik Iklan terhadap keputusan menyumbang koefisien korelasi sebesar 0.629. Hasil hubungan sedang program acara konser Tombo Kangen In Memoriam Didi Kempot dan Daya Tarik Iklan terhadap keputusan melaksanakan donasi koefisien korelasi sebesar 0.489. Uji Hipotesis didapatkan bahwa Ha diterima dan Ho ditolak, terdapat pengaruh hubungan kuat program acara konser Tombo Kangen In Memoriam Didi Kempot dan daya Tarik iklan terhadap keputusan melaksanakan donasi.
\end{abstract}

Kata Kunci: Program Acara, Konser Tombo Kangen, Didi Kempot, Daya Tarik Iklan, Keputusan Melakukan Donasi,

\section{THE INFLUENCE OF NEWS REPLACEMENT IN ONLINE MEDIA AND WORD OF MOUTH COMMUNICATIONS ON DECISION MAKING IN REDUCE PLASTIC USE WHEN SHOPPING (Survey of Minimarket Customers in Denpasar, Bali)}

\begin{abstract}
Tombo Kangen In Memoriam Didi Kempot concert program is broadcast digitally live on iNews Monday, May 25, 2020 while collecting funds for restoration of the legendary campursari by 30 percent and 70 percent will be coordinated by the Ngawi Regency Government through Bank Jatim to be returned to the Ngawi area and distributed to the Ngawi area corona victims The research objective is to find out how much influence the Tombo Kangen In Memoriam Didi Kempot concert program and the Attraction of Advertisements Against the Decision to Conduct a Donation. This study uses the Sociopsychological tradition and the Elaboration Likehood (ELT) Theory. The research design uses the Positivism Paradigm, Quantitative Approach, Exploration Types and Survey Methods. The population is 525,000 respondents @ didikempt_oficial, and a sample of 100 respondents. The results obtained low relationship program Tombo Kangen In Memoriam Didi Kempot concert program on the decision to donate the correlation coefficient of 0.312. The moderate relation of attractiveness of advertising to the decision contributed a correlation coefficient of 0.629. The result of the relationship being Tombo Kangen In Memoriam Didi Kempot's concert program and the Attraction of Advertising on the decision to donate a correlation coefficient of 0.489. The Hypothesis Test found that Ha was accepted and Ho was rejected, there was a strong relationship between the Tombo Kangen In Memoriam Didi Kempot concert program and the attractiveness of advertising towards the decision to make a donation.
\end{abstract}

Keyword: Concert program, Tombo Kangen concert, Didi Kempot, Attraction of Advertisements, Decision to Conduct a Donation. 
Korespondensi: Dr. Ilona Vicenovie Oisina. Universitas Persada Indonesia, Jakarta. Jl. Diponegoro No. 74 Jakarta Pusat 10340. No. HP, WhatsApp: 081511617896 Email: ilonaoisina@yahoo.com

PENDAHULUAN

Program acara yang disiarkan melalui televisi dapat menarik perhatian khalayak dengan penyajian yang menarik dan dibawakan pada momen yang tepat. Namun pada masa pandemic seperti ini banyak program acara termasuk acara konser yang biasa dilakukan di studio ataupun digelar disuatu tempat yang dapat menghadirkan banyak massa, namun untuk memenuhi syarat protokol kesehatan dilakukan secara interaktif dari rumah dan studio untuk mengurangi interaksi tatap muka dengan banyak orang. Namun jika program acara konser dirancang dengan baik tidak kalah menarik dengan program acara konser yang dilakukan full distudio ataupun disuatu tempat penyelenggara.

Tolak ukur keberhasilan suatu acara televisi dalam menjaring penonton selama ini dapat dilihat dari posisi rating program acara tersebut. Program acara merupakan gambaran akan jumlah penonton yang mengkonsumsi siaran televisi yang dikeluarkan oleh sebuah stasiun televisi (Hatta dan Arditta, 2016)1 Salah satu program acara konser yang sukses digelar dengan konsep memenuhi protokol kesehatan di masa pandemic adalah Didi Kempot Konser Amal Dari Rumah, dimana pada konser amal ini untuk mengumpulkan dana yang akan disumbangkan kepada masyarakat yang terkena dampak dari Covid-19, yang dilakukan pada hari Sabtu (11/4/2020) yang disiarkan langsung oleh Kompas TV. Pada konser ini menghasilkan total donasi yang tercatat per tanggal
14 April 2020, yakni Rp7,313,232,836. Dalam konser yang berlangsung selama tiga jam Didi Kempot mengingatkan Sobat Ambyar serta masyarakat Indonesia agar tidak mudik ke kampung halaman. Didi kempot menjelaskan langkah tersebut sebagai pencegahan penyebaran virus corona dan mendukung program pemerintah untuk tidak mudik saat hari raya Idul Fitri (Kompas Selasa, 14 April 2020, 21:04 WIB)2.

Televisi mampu menyebarkan informasi secara serentak dan ditonton oleh berbagai kalangan (Damayanti dkk, 2012)3. Program acara televisi dirancang sedemikian rupa agar dapat menarik minat penonton. Didi Kempot merupakan salah satu artis campur sari yang aktif dalam membantu pemerintah untuk menunda mudik dimasa pandemic agar dapat memutuskan mata rantai penyebaran virus corona di Indonesia, bahkan sampai menciptakan lagu Ojo Mudik untuk mengingatkan sobat ambyar dan seluruh masyarakat Indonesia untuk tidak mudik dimasa pandemic seperti ini. Namun pada tanggal 5 Mei 2020 Didi Kempot dikabarkan meninggal dunia di RS Kasih Ibu Solo Pukul 07.30 WIB yang mengejutkan banyak pihak. Konser amal dari rumah merupakan konser terakir yang dilakukan Didi Kempot untuk membantu sesama yang terkena dampak Covid-19. Tahun 2019 merupakan masa kejayaan Didi Kempot, dengan muncullah berbagai sebutan untuk Didi Kempot seperti Godfather of Broken Heart, Sobat Ambyar, Sadbois, Sadgels, Lord Didi, dan Bapak Loro Ati 
Nasional. Lagu-lagu Didi semuanya berbahasa Jawa dan hanya dinikmati penutur bahasa itu, kini semua kalangan seperti terkena sihir patah hati Lord Didi (Kompas.com Minggu, 20 Oktober 2019, 20:27 WIB)4.

Penggemar lagu-lagu pria asal Solo, Jawa Tengah, itu kini tidak terbatas pada kalangan orang tua atau generasi pada masa lagu-lagunya pertama kali dirilis. Didi Kempot mampu merebut hati anak muda seantero Nusantara. Didi Kempot mampu menyatukan kelompok pencinta lagu jawa dan kelompok generasi milenial. Kurang lebih 800 judul lagu Bahasa Jawa diciptakan oleh Didi Kempot. Nama dan syair lagu Didi Kempot ternyata tidak hanya masyhur di tanah air melainkan juga di luar negeri. Karya-karya Didi Kempot ternyata telah lama dikenal dan dinikmati oleh masyarakat di Suriname dan masyarakat Jawa yang menetap di Belanda.

Selama masa pandemi Lord Didi begitu sapaan akrabnya, sangat gencar membuat konser amal untuk mengurangi derita rakyat yang terkena dampak langsung dari penyakit tersebut, bahkan dia sempat ingin membuat konser amal lainnya di kampung halaman. Selain menggalang dana untuk menangani dampak Covid-19, konser ini dimaksudkan agar masyarakat Ngawi yang ada di daerah manapun tidak pulang kampung untuk meminimalisir penyebaran pandemi ini di Tanah Air. Namun, Tuhan telah memanggilnya terlebih dahulu sebelum niat baik ini terlaksana.

Untuk menghargai dan mengenang jasa-jasa Didi Kempot salah satu stasiun televisi mengadakan program acara konser dengan judul
Tombo kangen In Memoriam Didi Kempot yang disiarkan iNews TV dari Gedung Eka Kapti, Ngawi, Jawa Timur, Senin (25/5) malam. Untuk mengenang jasa Didi Kempot, Pemerintah Kabupaten Ngawi mengadakan konser amal yang dipandu oleh pembawa acara Elisabeth Sudira dan Budi Sulistyono yang juga Bupati Ngawi. Dimeriahkan oleh berbagai artis lagu tradisional, Dory Harsa dan Ardha yang merupakan salah satu teman duet Didi Kempot dan menggunakan group band Lare Jawi yang merupakan band pengiring Didi Kempot setiap melakukan konsernya diseluruh Indonesia.

Dalam konser ini, interaktif dengan berbagai tokoh politik, diantaranya Sekretaris Kabinet RI Pramono Anung, Sekjen PDIP Hasto Kristiyanto, Wakil Gubernur Jawa Timur Emil Dardak, Wali Kota Surabaya Tri Rismaharini, Bupati Trenggalek Muchamad Nur Arifin, dan Bupati Banyuwangi Abdullah Azwar Anas. Konser ini dihadiri oleh Istri pertama Didi Dores Ibu $\mathrm{Hj}$ Saputri dan atas izinnya konser amal ini dilakukan selama satu setengah jam menggalang dana untuk masyarakat yang terkena dampak Covid-19 dan pemugaran makam Didi Kempot di Ngawi. Dalam acara konser ini dimeriahkan oleh artis keroncong dan artis penyanyi lagu tradisional yang membawakan berbagai lagu-lagu ciptaan Didi Kempot.

Acara konser digital Tombo Kangen ini diisi oleh berbagai iklan produk dan jasa selama acara ini berlangsung. Media merupakan sasaran pembuat iklan untuk mengiklankan berbagai 
produk dan layanan suatu produk (Situmeang, 2019)5.

Televisi merupakan media iklan yang unik namun memiliki kekuatan sangat besar (powerfull) karena memiliki elemen audio dan visual yang membuka peluang untuk mewujudkan berbagai gagasan kreatif sehingga mampu menciptakan daya tarik audience televisi (Situmeang, 2013)6. Kebanyakan iklan yang berhubungan dengan pemerintah Jawa Timur, diantaranya iklan Bank Jatim, merupakan bank yang digunakan untuk menyimpan dana pada konser ini, selain itu juga ada iklan dari salah satu fashion Batik di daerah Ngawi, Iklan pupuk, iklan pariwisata Ngawi dan kuliner yang ada di Nagwi dan Jawa Timur. Iklaniklan yang ada selama konser digital ini berlangsung sengaja dibuat yang berhubungan dengan Ngawi dan Jawa Timur untuk memperkenalkan wilayah Ngawi serta untuk mengobatin rasa kangen masyarakat Ngawi yang tidak bisa mudik pada saat hari Raya Idul Fitri.

Iklan-iklan dalam konser digital Tombo Kangen IN Memoriam ini sebagai media promosi untuk menarik perhatian dan minat khalayak penonton. Iklan yang disajikan selama konser digital ini berlangsung memiliki daya tarik tersendiri terutama untuk masyarakat Ngawi dan Jawa Timur yang tidak bisa mudik pada saat Idul Fitri berlangsung, sekaligus juga untuk memperkenalkan daerah wisata, kuliner dan wilayah di Ngawi untuk masyarakat Indonesia yang belum pernah datang ke Ngawi. Acara konser digital dan daya Tarik iklan yang berlangsung selama satu setengah jam ini bertujuan untuk menarik perhatian seluruh masyarakat Indonesia untuk mengingat Kembali jasa Didi Kempot sebagai penyanyi campur sari yang memperkenalkan lagu tradisional Jawa di Indonesia dan dimancanegara yaitu di Suriname dan di Belanda.

Konser digital dan daya Tarik iklan yang disiarkan ini diharapkan dapat menarik perhatian masyarakat Indonesia untuk dapat tergerak hatinya melakukan keputusan untuk menggalang dana bagi masyarakat yang terkena dampak Covid-19 dan juga untuk melakukan pemugaran kuburan sang maestro Didi Kempot yang terletak dikota Ngawi, Jawa Timur. Dana yang terkumpul melalui Bank Jawa Timur Donasi yang terkumpul melalui rekening PMI Ngawi sebesar Rp115.404.200,selama satu setengah jam berlangsung. Hal ini menunjukkan bahwa masyarakat Indonesia memiliki rasa solidaritas yang tinggi menggalang dana untuk kemanusiaan.

Sementara donasi yang terkumpul selama konser digital berlangsung atas persetujuan istri Didi Kempot, 30 persen akan diperuntukan bagi pemugaran pemakam tempat sang legenda dimakamkan, dan 70 persen yang dikelolah pemkab Ngawi melalui Bank Jatim akan mengembalikan dana donasi ke asal donatur agar didistribusikan kepada korban Covid-19 di daerahnya.

Selama konser berlangsung Istri Didi Kempot, Saputri dan anaknya Siola tampil dalam acara konser tersebut. Konser digital itu untuk mengenang Didi Kempot dan bantuan korban Covid-19. Saputri pertama kali bersedia tampil 
dilayar televisi pasca meninggalnya sang suami.Istri Alm Didi Kempot Ibu $\mathrm{Hj}$ Saputri menikmati berbagai lantunan lagu karya suami tercinta. Dan dengan izin Ibu $\mathrm{Hj}$ saputri kegiatan amal ini juga dikembalikan untuk masyarakat Indonesia. Bupati Ngawi Budi Kanang Sulistyono menyampaikan acara ini momen yang luar biasa, karena semua bekerja maksimal demi mengenang almarhum Didi Kempot. Acara digital ini juga memberi hiburan kepada para perantau yang tidak pulang kampung halaman akibat larangan mudik.

\section{METODE PENELITIAN}

\section{Desain Penelitian}

Dalam penelitian ini, menggunakan paradigma positivistic, menggunakan pendektakan kuantitatif dengan jenis penelitian eksplanatif dan metode penelitian dengan cara survei.

Populasi dalam penelitian ini adalah followers didikempot-official sebanyak 525.000 pada tanggal 30 Mei 2020.

Sampel penelitian menggunakan rumus Slovin.Dengan menggunakan presisi sebesar 10\%, dengan rumus Slovin yaitu:

$$
\begin{aligned}
& \mathrm{n}=\mathrm{N} /(1+\llbracket \mathrm{Ne} \rrbracket \wedge 2) \\
& \mathrm{n}=\mathrm{N} /(1+\llbracket \mathrm{Ne} \rrbracket \wedge 2) \\
& \mathrm{n}=525.000 /(1+(525.000) \llbracket(0,1) \rrbracket \wedge 2) \\
& \mathrm{n}=525.000 / 5251
\end{aligned}
$$

$\mathrm{n}=99,981 \mathrm{n}=100$ responden

Berdasarkan perhitungan rumus Slovin, peneliti menetapkan sampel dalam penelitian ini adalah sejumlah 100 responden.

Penarikan sampel non probability sampling. Non probability sampling dengan cara purposive sampling, yang merupakan teknik penentuan sampel dengan pertimbangan tertentu (Sugiyono, 2013:68)12 Karakteristik pertimbangan tertentu yang ditetapkan peneliti, yaitu:

Followers Didi Kempot official

Menonton Acara Tombo Kangen In memoriam

\section{Teknik Analisa Data}

Uji Validitas merupakan cara untuk mengukur ketepatan alat ukur. Suatu alat ukur mempunyai reabilitas tinggi atau dapat dipercaya, jika alat ukur stabil, dapat diandalkan dan dapat diramalkan. (Nazir, 2014:117)13.

Uji Reliabilitas merupakan alat ukur disebut reliabel bila alat ukur tersebut secara konsisten memberikan hasil atau jawab yang sama terhadap gejala yang sama, walau digunakan berulang kali. Reliabilitas mengandung arti bahwa alat ukur tersebut stabil (tidak berubah-ubah), dapat diandalkan (dependable), dan tetap (consistent). (Kriyantono, 2012:145)14.

Uji korelasi dapat didefinisikan sebagai hubungan atau keeratan antara 2 variabel atau lebih, dimana variabel lainnya dianggap sebagai kontrol atau pengendali. Nilai korelasi berkisar antara -1 hingga +1 . Nilai yang mendekati -1 atau +1 menyatakan hubungan semakin kuat, sedangkan nilai yang mendekati angka 0 dikatakan memiliki hubungan lemah. Nilai positif menyatakan arah hubungan searah (jika $\mathrm{X}$ naik, maka Y naik), sebaliknya bila nilai yang dihasilkan negatif maka menyatakan arah hubungan terbalik (jika X naik, maka Y turun) (Kurniawan, 2010)15.

Uji korelasi berganda adalah untuk mengetahui derajat atau kekuatan antara hubungan tiga variabel 
atau lebih, serta mengetahui kontribusi yang di berikan secara simultan oleh variabel X1 dan X2 terhadap nilai variabel $\mathrm{Y}$ dan kontribusi secara parsial yang diberikan variabel X1 terhadap Y serta X2 terhadap Y. (Siregar, 2015:262) 16

Uji regresi dilakukan jika korelasi antara 2 variabel mempunyai hubungan kausal (sebab-akibat) atau hubungan fungsional. Regresi ditunjukan untuk mencari bentuk hubungan 2 variabel atau lebih dalam bentuk fungsi atau persamaan.

Uji T digunakan untuk mengetahui sumbangan variabel bebas secara parsial terhadap variabel terikat, menggunakan uji masing-masing koefisien regresi variabel bebas apakah mempunyai pengaruh yang bermakna atau tidak terhadap variabel terikat (Sugiyono, 2019).

Uji F digunakan untuk mengetahui apakah secara simultan atau bersama-sama koefisien variabel bebas mempunyai pengaruh yang nyata atau tidak terhadap variabel terikat. Untuk menguji apakah masing-masing variabel bebas berpengaruh secara signifikan terhadap variabel terikat secara bersama-sama dengan $\alpha=0.05$.

\section{HASIL DAN PEMBAHASAN}

\section{Hasil Uji Validitas}

Tabel 1: Hasil Uji Validitas Variabel X1

\begin{tabular}{|c|c|c|c|}
\hline Pernyataan & $\begin{array}{c}\mathbf{R} \\
\text { Hitung }\end{array}$ & $\begin{array}{c}\mathbf{R} \\
\text { Tabel }\end{array}$ & Keterangan \\
\hline X1 P1 & 0.039 & 0.361 & Tidak Valid \\
\hline X1 P2 & 0.467 & 0.361 & Valid \\
\hline X1 P3 & 0.518 & 0.361 & Valid \\
\hline X1 P4 & 0.390 & 0.361 & Valid \\
\hline X1 P5 & 0.105 & 0.361 & Tidak Valid \\
\hline X1 P6 & 0.662 & 0.361 & Valid \\
\hline X1 P7 & 0.485 & 0.361 & Valid \\
\hline X1 P8 & 0.699 & 0.361 & Valid \\
\hline X1 P9 & 0.542 & 0.361 & Valid \\
\hline X1 P10 & 0.216 & 0.361 & Tidak Valid \\
\hline X1 P11 & 0.621 & 0.361 & Valid \\
\hline X1 P12 & 0.437 & 0.361 & Valid \\
\hline X1 P13 & 0.560 & 0.361 & Valid \\
\hline X1 P14 & 0.149 & 0.361 & Tidak Valid \\
\hline
\end{tabular}

\begin{tabular}{|l|l|l|l|}
\hline X1 P15 & 0.671 & 0.361 & Valid \\
\hline
\end{tabular}

\section{Sumber: Data Kuisioner Diolah SPSS Versi 25.0}

Berdasarkan tabel tersebut, dapat disimpulkan bahwa dari 15 butir pernyataan variabel Program Acara (X1), butir pernyataan tidak valid sebanyak 4 buah butir pernyataan yaitu pernyataan X1 P1 sebesar 0.039 dan X1 P5 sebesar 0.105. X1 P10 sebesar 0,216 dan X1 P14 sebesar 0.149 Hal Tidak valid dapat diartikan karena ke empat butir pernyataan tersebut memiliki nilai $r$ hitung lebih kecil dari 0.361 (r tabel). Butir pernyataan yang tidak valid akan dihapus dan tidak layak digunakan untuk kuesioner selanjutnya. Pernyataan yang valid sebanyaknya 11 butir pernyataan tersebut akan digunakan untuk penelitian selanjutnya dengan sampel penelitian sebesar 99 responden. Sedangkan butir pernyataan lainnya valid karena memiliki nilai $r$ hitung lebih besar dari $r$ tabel

Tabel 2: Hasil Uji Validitas Variabel X2

\begin{tabular}{|c|c|c|c|}
\hline Pernyataan & $\begin{array}{c}\mathbf{R} \\
\text { Hitung }\end{array}$ & $\begin{array}{c}\mathbf{R} \\
\text { Table }\end{array}$ & Keterangan \\
\hline X2 P1 & 0.398 & 0.361 & Valid \\
\hline X2 P2 & 0.521 & 0.361 & Valid \\
\hline X2 P3 & 0.498 & 0.361 & Valid \\
\hline X2 P4 & 0.601 & 0.361 & Valid \\
\hline X2 P5 & 0.221 & 0.361 & Tidak Valid \\
\hline X2 P6 & 0.557 & 0.361 & Valid \\
\hline X2 P7 & 0.476 & 0.361 & Valid \\
\hline X2 P8 & 0.321 & 0.361 & Tidak Valid \\
\hline X2 P9 & 0.476 & 0.361 & Valid \\
\hline
\end{tabular}

Sumber: Data Kuisioner Diolah SPSS Versi 25.0

Berdasarkan tabel diatas, dapat disimpulkan bahwa terdapat 9 butir variabel Daya Tarik Iklan (X2), terdapat 2 butir pernyataan yang tidak valid yaitu pernyataan X2 P5 sebesar 0.221 dan X1 P8 sebesar 0.321 . Tidak valid diartikan karena ke empat butir pernyataan tersebut memiliki nilai $r$ hitung lebih kecil dari 0.361 ( $\mathrm{r}$ tabel). Butir pernyataan yang tidak valid akan dieliminasi dan tidak layak 
digunakan untuk kuesioner selanjutnya. Butir pernyataan yang tidak valid akan dihapus dan tidak layak digunakan untuk kuesioner selanjutnya. Pernyataan yang valid sebanyak 7 buah pernyataan. Dapat diartikan 7 butir pernyataan tersebut memiliki $r$ hitung lebih besar dari $r$ tabel. Pernyataan yang valid siap digunakan untuk penelitian selanjutnya dengan sampel sebesar 99 responden. Sedangkan butir pernyataan lainnya valid karena memiliki nilai $r$ hitung lebih besar dari r tabel.

Tabel 3: Hasil Uji Validitas Variabel Y

\begin{tabular}{|c|c|c|c|}
\hline Pernyataan & $\begin{array}{c}\text { R } \\
\text { Hitung }\end{array}$ & $\begin{array}{c}\text { R } \\
\text { Table }\end{array}$ & Keterangan \\
\hline Y P1 & 0.763 & 0.361 & Valid \\
\hline Y P2 & 0.802 & 0.361 & Valid \\
\hline Y P3 & 0.639 & 0.361 & Valid \\
\hline Y P4 & 0.565 & 0.361 & Valid \\
\hline Y P5 & $\mathbf{0 . 2 5 6}$ & $\mathbf{0 . 3 6 1}$ & Tidak Valid \\
\hline Y P6 & 0.573 & 0.361 & Valid \\
\hline Y P7 & 0.702 & 0.361 & Valid \\
\hline Y P8 & $\mathbf{0 . 3 1 1}$ & $\mathbf{0 . 3 6 1}$ & Tidak Valid \\
\hline Y P9 & 0.405 & 0.361 & Valid \\
\hline Y P10 & $\mathbf{0 , 1 2 3}$ & $\mathbf{0 . 3 6 1}$ & Tidak Valid \\
\hline Y P11 & 0.459 & 0.361 & Valid \\
\hline Y P12 & 0.557 & 0.361 & Valid \\
\hline
\end{tabular}

Sumber: Data Kuisioner Diolah SPSS Versi 25.0

Berdasarkan tabel tersebut, dapat disimpulkan bahwa dari 12 butir pernyataan dalam kuesioner untuk variabel Keputusan Menyumbang (Y), butir pernyataan yang tidak valid sebanyak 3 buah butir pernyataan yaitu pernyataan Y P5 sebesar 0.256 dan Y P8 sebesar 0.311 dan Y P10 sebesar 0,123. Hal tersebut tidak valid dapat diartikan karena ke empat butir pernyataan tersebut memiliki nilai $r$ hitung lebih kecil dari 0.361 ( $\mathrm{r}$ tabel). Butir pernyataan yang tidak valid akan dihapus dan tidak layak digunakan untuk kuesioner selanjutnya.
Pernyataan yang valid sebanyaknya 9 butir pernyataan tersebut akan digunakan untuk penelitian selanjutnya dengan sampel penelitian sebesar 99 responden. Sedangkan butir pernyataan lainnya valid karena memiliki nilai $\mathrm{r}$ hitung lebih besar dari $r$ tabel.

\section{Hasil Uji Reliabilitas}

Tabel 4: Hasil Uji Reliabilitas Variabel X1

\begin{tabular}{|r|r|}
\hline \multicolumn{2}{|c|}{ Reliability Statistics } \\
\hline Cronbach's Alpha & N of Items \\
\hline .874 & \\
\hline
\end{tabular}

Sumber: Data Kuisioner Diolah SPSS Versi 25.0

Hasil uji reliabilitas untuk variabel Program Acara (X1), diperoleh koefisien reabilitas Cronbach Alpha sebesar 0.874. Dengan hasil tersebut, maka dapat dikatakan bahwa variabel tersebut adalah reliabel karena memberikan nilai Cronbach Alpha (a) > 0,60.

\section{Tabel 5: Hasil Uji Reliabilitas Variabel X2}

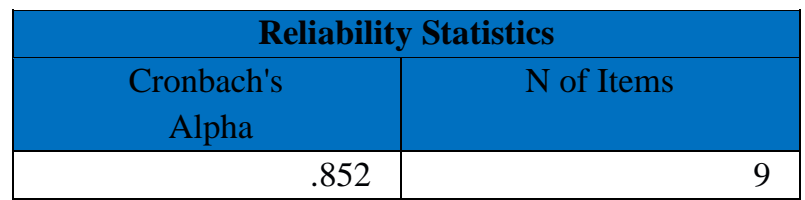

Sumber: Data Kuisioner Diolah SPSS Versi 25.0

Hasil perhitungan uji reliabilitas untuk variabel Daya Tarik Iklan (X2), diperoleh koefisien reabilitas Cronbach Alpha sebesar 0.852. Dengan hasil tersebut, maka dapat dikatakan bahwa variabel tersebut adalah reliabel karena memberikan nilai Cronbach Alpha (a) > 0,60.

Tabel 5: Hasil Uji Reliabilitas Variabel X2

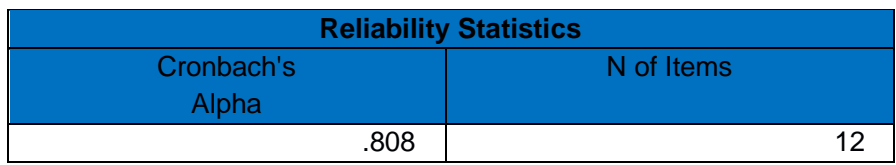

Sumber: Data Kuisioner Diolah SPSS Versi 25.0

Hasil perhitungan uji reliabilitas untuk variabel Keputusan Melakukan donasi (Y), diperoleh 
koefisien reabilitas Cronbach Alpha sebesar 0.808. Dengan hasil tersebut, maka dapat dikatakan bahwa variabel tersebut adalah reliabel karena memberikan nilai Cronbach Alpha (a) > 0,60

\section{ANALISIS DATA}

\section{Uji Korelasi}

Tabel 6: Hasil Uji Korelasi Sederhana

\begin{tabular}{|c|c|c|c|c|}
\hline \multicolumn{5}{|c|}{ Correlations } \\
\hline & & $\begin{array}{c}\text { SKOR } \\
\text { PA }\end{array}$ & $\begin{array}{l}\text { SKOR } \\
\text { DTI }\end{array}$ & $\begin{array}{l}\text { SKOR } \\
\text { KMD }\end{array}$ \\
\hline \multirow[t]{3}{*}{$\begin{array}{l}\text { SKOR } \\
\text { PA }\end{array}$} & $\begin{array}{l}\text { Pearson } \\
\text { Correlation }\end{array}$ & 1 & $.602^{* *}$ &.$^{* *}$ \\
\hline & Sig. (2-tailed) & & .000 & .000 \\
\hline & $\mathrm{N}$ & 99 & 99 & 99 \\
\hline \multirow[t]{3}{*}{$\begin{array}{l}\text { SKOR } \\
\text { DTI }\end{array}$} & $\begin{array}{l}\text { Pearson } \\
\text { Correlation } \\
\end{array}$ & $.602^{* * *}$ & 1 & $.629^{* *}$ \\
\hline & Sig. (2-tailed) & .000 & & .000 \\
\hline & $\mathrm{N}$ & 99 & 99 & 99 \\
\hline \multirow[t]{3}{*}{$\begin{array}{l}\text { SKOR } \\
\text { KMD }\end{array}$} & $\begin{array}{l}\text { Pearson } \\
\text { Correlation } \\
\end{array}$ & $.312^{* *}$ & $.629^{* *}$ & 1 \\
\hline & Sig. (2-tailed) & .000 & .000 & \\
\hline & $\mathrm{N}$ & 99 & 99 & 99 \\
\hline
\end{tabular}

Sumber: Data Kuisioner Yang Diolah SPSS Versi 25.0

Hasil uji korelasi antara variabel X1 (Program Acara) dan Y (Keputusan Melakukan donasi), dapat disimpulkan menjadi 3 poin:

1. Terdapat hubungan variabel $\mathrm{X} 1$ dan $\mathrm{Y}$, hal ini dapat dilihat dari nilai Sig menunjukan nilai 0.000 dimana nilai tersebut lebih kecil dari 0.05.

2. Hubungan antara 2 variabel tersebut adalah hubungan yang positif, yang artinya apabila terdapat peningkatan pada variabel Program Acara maka Keputusan Menyumbang juga akan mengalami peningkatan.

3. Nilai koefisien korelasi Pearson Correlation sebesar 0.312. Tingkat hubungan antara kedua variabel termasuk dalam korelasi rendah, karena berada dalam interval 0.200-0.399 dengan tingkat hubungan rendah.

Hasil uji korelasi antara variabel X2 (Daya Tarik Iklan) dan Y (Keputusan Melakukan donasi), dapat disimpulkan menjadi 3 poin:

1. Terdapat hubungan variabel $\mathrm{X} 2$ dan $\mathrm{Y}$, hal ini dapat dilihat dari nilai Sig menunjukan nilai 0.000 dimana nilai tersebut lebih kecil dari 0.05.

2. Hubungan antara 2 variabel tersebut adalah hubungan yang positif, yang artinya apabila terdapat peningkatan pada variabel Daya Tarik Iklan maka juga akan mengalami peningkatan.

3. Nilai koefisien korelasi Pearson Correlation sebesar 0.629. Tingkat hubungan antara kedua variabel termasuk dalam korelasi sedang, karena berada dalam interval 0.600-0.799 dengan tingkat hubungan kuat.

\section{Hasil Analisis Korelasi Berganda Korelasi Berganda}

TABEL 7: Hasil Uji Korelasi Berganda

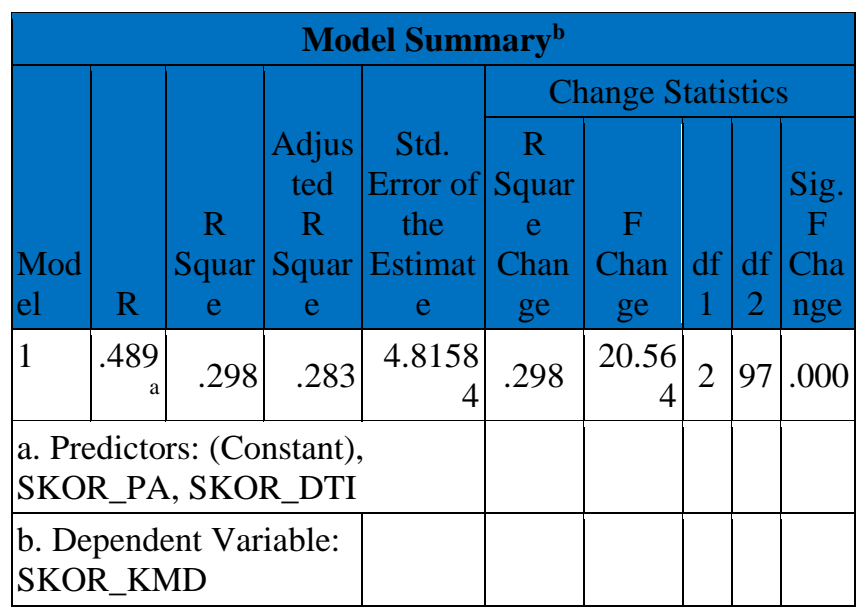

Sumber: Data Kuisioner Yang Diolah SPSS Versi 25.0

Berdasarkan hasil tabel tersebut, diperoleh nilai koefisien $(\mathrm{R})$ sebesar 0,489 Koefisien korelasi memiliki hubungan positif dengan tingkat hubungan yang termasuk korelasi sedang, karena berada dalam interval 0,400-0,699 dengan tingkat hubungan yang sedang. Ini berarti terdapat 
hubungan positif yang sedang antara program acara dan daya tarik iklan maka keputusan melakukan donasi juga akan mengalami peningkatan.

\section{Uji Regresi}

\begin{tabular}{|c|c|c|c|c|c|}
\hline \multicolumn{6}{|c|}{ Coefficients $^{\mathbf{a}}$} \\
\hline \multirow[b]{2}{*}{ Model } & \multicolumn{2}{|c|}{$\begin{array}{c}\text { Unstandardized } \\
\text { Coefficients }\end{array}$} & $\begin{array}{c}\text { Standardized } \\
\text { Coefficients }\end{array}$ & $\mathrm{t}$ & Sig. \\
\hline & B & Std. Error & Beta & & \\
\hline \multirow[t]{3}{*}{$1 \quad$ (Constant) } & 1.519 & 4.531 & & .317 & .692 \\
\hline & .201 & .203 & .152 & 1.395 & .150 \\
\hline & .481 & .112 & .442 & 4.148 & .000 \\
\hline
\end{tabular}

a. Dependent Variable: SKOR_KMD

Sumber: Data Kuisioner Yang Diolah SPSS Versi 25.0

$\mathrm{Y}=\mathrm{a}+\mathrm{b} 1 \mathrm{X} 1+\mathrm{b} 2 \mathrm{X} 2$

$\mathrm{Y}=1,519+0,201 \mathrm{X} 1+0,481 \mathrm{X} 2$

Hasil terlihat variabel program acara Tombo Kangen In Memoriam Didi Kempot dianggap konstan, maka nilai Keputasan Melakukan Donasi sebesar 1,519 satuan. Apabila nilai program acara Tombo Kangen In Memoriam Didi Kempot mengikat satuan-satuan dan nilai daya Tarik iklan adalah konstan, maka nilai Keputusan Melakukan Donasi meningkat 0,258 satuan. Apabila nilai Daya Tarik Iklan meningkat satuan-satuan dan nilai program acara Tombo kangen In Memoriam Didi Kempot adalah konstan, maka nilai Keputusan Melakukan Donasi akan meningkat 0,481 satuan.

\section{Uji T}

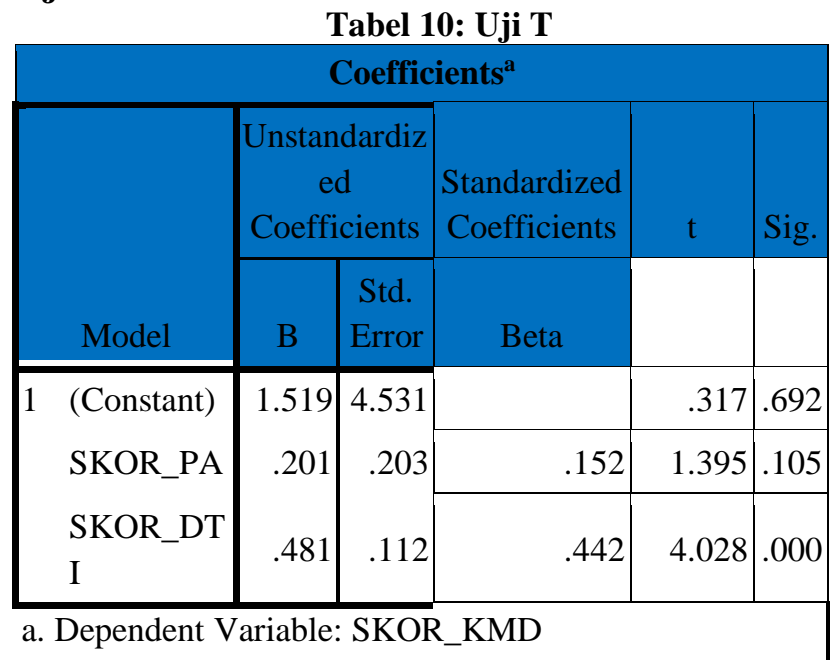

a. Predictor : (Constant) : terpaan pemberitaan media online, Word of Mouth Communications

b. Dependent Variabel: Pengambilan Keputusan

Sumber: Data Kuisioner Yang Diolah SPSS Versi 25.0

Berdasarkan tabel 4.5 menunjukkan hasil signifikansi dari hasil uji F yang menunjukkan nilai f hitung sebesar 20,143 dan nilai sig sebesar 0,000. Maka diketahui bahwa nilai f hitung lebih besar dari f tabel $(3,09)$ dan nilai sig lebih kecil dari 0,05 . Dapat dikatakan bahwa variabel independen secara simultan mempengaruhi variabel dependen. Ho ditolak dan Ha diterima. Dengan demikian peneliti menyimpulkan bahwa terdapat pengaruh antara Program Acara program acara Tombo Kangen In Memoriam Didi Kempot dan Daya Tarik Iklan Konsumen terhadap Keputusan Melakukan Donasi.

Hasil penelitian ini memperkuat pernyataan Belch dan Belch (2001:275)17 yang menyatakan bahwa daya tarik iklan mengacu pada pendekatan yang digunakan untuk menarik perhatian konsumen dan atau memengaruhi perasaan mereka terhadap suatu produk (barang dan jasa) untuk tujuan periklanan secara sempit dan tujuan promosi secara luas. Hasil penelitian ini mendukung penelitian yang dilakukan Martopo (2015)18 bahwa iklan harus berani menawarkan suatu kreativitas, agar terlihat berbeda dari yang lainnya. Pesan yang disampaikan harus jelas dan terarah, agar dapat menciptakan daya tarik tersendiri. IkIan yang menarik dan kreatif akan mampu mempenaruhi Keputusan melakukan Tindakan dalam hal ini donasi. IkIan yang menarik dan kreatif tentunya akan mempengaruhi Keputusan khalayak dimana hasil 
yang didapatkan oleh penelitian terdahulu mengatakan bahwa pengaruh secara bersama-sama pada daya tarik iklan rasional dan daya tarik iklan emosional terhadap keputusan pembelian (Putra, 2015)19 dalam hal keputusan dalam melakukan donasi.

\section{SIMPULAN}

Pengaruh program acara Tombo Kangen In Memoriam Didi Kempot memiliki hubungan positif dan sedang dengan keputusan melakukan donasi sebesar 0,391 atau 39,1\%. Daya Tarik Iklan memiliki hubungan positif dan sedang dengan keputusan melakukan donasi sebesar 0,427 atau $42,7 \%$. Pengaruh program acara Tombo Kangen In Memoriam Didi kempot dan daya Tarik iklan memiliki hubungan yang positif dan sedang dengan keputusan melakukan donasi sebesar 0,494 atau $49,4 \%$.

Nilai t hitung variabel program acara Tombo Kangen In Memoriam Didi Kempot sebesar 3,685> t tabel 1.662 Maka dapat disimpulkan bahwa H0 ditolak dan Ha diterima yang artinya " Pengaruh program acara Tombo Kangen In Memoriam Didi kempot berpengaruh positif terhadap keputusan melakukan donasi. Nilai t hitung untuk daya Tarik iklan sebesar 3,917 > t tabel 1.662. Maka dapat disimpulkan bahwa H0 ditolak dan Ha diterima yang artinya "daya Tarik iklan berpengaruh positif terhadap keputusan melakukan donasi”. Pada uji F didapatkan hasil sebesar 15.768 sedangkan F tabel sebesar 3,099. Maka F hitung > dari F tabel yaitu $15.768>3.099$, dapat disimpulkan bahwa terdapat pengaruh secara simultan program acara Tombo
Kangen In Memoriam Didi Kempot dan Daya Tarik Iklan terhadap keputusan melakukan donasi.

Berdasarkan hasil penelitian yang telah dibahas sebelumnya, maka peneliti ingin memberikan saran terkait dengan hasil penelitian ini, yakni: Agar program acara dapat terus memberikan tontonan yang menarik dan berkualitas perlu diperhatikan siapa yang menjadi penontonnya sehingga disesuai dengan minat dari penonton, durasi penanyangan program acara dan waktu penanyangan sehingga sesuai dengan kebutuhan penonton. Daya Tarik iklan yang disajikan selama acara berlangsung dianggap bagus karena dapat memberikan kontribusi yang kuat terhadap keinginan penonton untuk melakukan donasi saat acara tersebut berlangsung. Daya Tarik iklan jika disesuai dengan acara yang sedang berlangsung akan memberikan kontribusi bagi keputusan melakukan donasi.

Disarankan untuk peneliti selanjutnya agar penelitian ini dapat dijadikan bahan pertimbangan serta menjadi bahan pembanding untuk penelitian serupa tentang daya tarik iklan rasional dan daya tarik iklan emosional terhadap keputusan pembelian. Sehingga, penelitian selanjutnya akan menghasilkan interpretasi yang berbeda dan dapat memperluas wawasan.

\section{DAFTAR PUSTAKA}

\section{Book}

Hatta, Holila dan Ardhita, Fajri. (2016). FAKTOR YANG MEMENGARUHI KEPUTUSAN KONSUMEN MENONTON PROGRAM ACARA DJARUM INDONESIA SUPER LEAGUE DI ANTV DI PROVINSI LAMPUNG. Prosiding Seminar Nasional INDOCOMPAC Universitas Bakrie, Jakarta. 2-3 Mei 2016 
Littlejohn, K. A. (2011). Teori Komunikasi edisi 9. In K. A. Littlejohn, pp. 64-65). Jakarta: Salemba Humanika.

Littlejohn, Stephen W., Karen A. Foss. 2016. Ensiklopedia Teori Komunikasi Jilid 1. Jakarta: Kencana.

Ardianto. Elvinaro. (2007). Komunikasi Massa Suatu Pengantar. Bandung: Simbiosa Rekatama Media.

Morissan. (2013). Teori Komunikasi: Individu Hingga Massa. Jakarta: Kencana Perdana Media Group.

Syamsi Ibnu. (2000). Pengambilan Keputusan Dan Sistem Infoemasi. Jakarta: Bumu Aksara.

Sugiyono. (2019). Metode Penelitian Kuantitatif, Kualitatif, dan $R \& D$. Bandung: Alfabeta.

Nazir, Moh. (2014). Metode Penelitian. Bogor: Ghalia Indonesia.

Kriyantono, Rachmat. (2012). Teknik Praktis Riset Komunikasi. Jakarta: Kencana Perdana.

Kurniawan, Albert. (2010). Belajar Mudah SPSS Untuk Pemula. Yogyakarta: Mediakom.

Siregar, Syofian. (2013). Metode Penelitian Kuantitatif Dilengkapi Dengan Perhitungan Manual dan SPSS. Jakarta: Kencana.

Belch, George E and A Michael Belch. 2001. Advertising \& Promotion: An Integrated Marketing Communication Perspective. New York: McGraw Hill

Martopo, A. Sulis. (2015). Pengaruh Kualitas Produk, Citra Merek dan Daya Tarik Iklan Terhadap Keputusan pembe lian Pada Produk Jamu Tolak Angin Pt. Sido Muncul. (Studi Pada Mahasiswa Fakultas Ekonomi Universitas Negeri Yogyakarta).Yogyakarta: Universitas Negeri Yogyakarta.

Putra, Cherry Amanca. (2015). Pengaruh Periklanan Rasional Dan Emosional Terhadap Keputusan pembelian Produk Sunsilk Pada Mahasiswa Fakultas Ekonomi Dan Bisnis Universitas Sumatera Utara. Sumatera Utara: Universitas Sumatera Utara.

\section{Jurnal online}

Damayanti, Amiruddin Saleh, Richard W.E. Lumintang. (2012). Mayor Komunikasi
Pembangunan Pertanian Dan Pedesaan, Efektivitas Variety Show Program Keluarga Berencana Melalui Media Televisi. Jurnal Komunikasi Pembangunan Juli 2012, Vol.10, No.2 hal 43

Situmeang Ilona Vicenovie Oisina, Ivonne Ruth Vitamaya Oishi. (2019). Pengaruh Daya Tarik Pesan Iklan Layanan Masyarakat Dan Tingkat Pengetahuan Masyarakat Terhadap Keputusan Menggunakan Vaksin Meales Dan Rubella (MR) Pada Anak (Studi Eksplanatif Pada Subscriber Iklan Layanan Masyarakat Vaksin Meales Dan Rubella Versi Panjang). Jurnal Komunida Media Komunikasi dan Dakwah, Vol 9 No 2 (2019).

Situmeang Ilona Vicenovie Oisina. (2013). Pengaruh Daya Tarik Iklan Televisi Cosmetik Wardah Terhadap Keputusan Pembelian. Jurnal Komunikasi Pembangunan Vol 11 No 2 (2013).

\section{Surat Kabar Online}

Kompas Total Donasi Sementara Konser Amal Didi Kempot Mencapai Rp7,3 Miliar Selasa, 14 April 2020. 21:04 WIB.

Kompas.com Minggu, 20 Oktober 2019. 20:27 WIB Sobat Ambyar dan Sihir Didi Kempot 